\title{
Civil Rights Of Children Outside Married Due Isbat Nikah Of Polygamy (Analysis of Islamic Court of Rembang Decision No. 99 / Pdt.G / 2018 / PA.Rbg.)
}

\author{
Rofi'atun $^{1}$, Akhmad Khisni $^{2}$ and Rozihan ${ }^{3}$
}

Abstract. This study discusses the civil rights of children outside the mating due to confirmation of marriage polygamy, Problems taken author in this thesis is how the legal protection of children outside marriage related his civil rights especially on custody of marriage and inheritance rights to men as fathers biological, because the Indonesian Constitution the Act of 1945 and other regulations related to children's rights requires such a case, article $28 \mathrm{~B} \mathrm{(2)}$ the result of amendments to the Act of 1945 states "Every child has the right to live, grow and develop and is entitled to protection from violence and discrimination, as well as the norms of Islamic law every child born in the holy predicate attached to him (Fitrah), so that the civil rights of Islam also guaranteed, regardless of whether the child was born out of and / or as a result of a legal marriage or a result of Sirri Marriage.

The research method used by writer is a normative juridical approach where the study was conducted based on legal materials main by way of studying the theories, concepts, principles of law, rule of law, court decisions and legislation relating to this study.

The results showed that based on the decision number: 99 / Pdt.G / 2018 / PA.Rbg, in the case of confirmation polygamous marriage, civil rights children outside marriage (polygamy) or Sirri equal to the rights of children born and / or result polygamous marriage is official, so that the legal rights of children outside marriage in the decision on child custody and inheritance rights equal to other biological children were born of the first marriage. thus based on the decision of the civil rights of children protected by law, to get justice, and the certainty of the status and civil rights.

Keywords: Civil Rights of Children Outside Marriage; Sirri Polygamy; Rights of Guardianship And Inheritance.

\section{Introductions}

Constitutional Court through its decision number 46 / PUU-VIII / 2010 dated February 13, 2012 has changed the legal norms of Article 43 paragraph (1) Act No. 1 of 1974, as amended by Act No. 16 in 2019 on marriage, additional State Gazette Republic of Indonesia Number 3019 that in the article as to read or to be read "Children born out of wedlock have a relationship of civil with her mother and her mother's family as well as with a man as his father can be proved by science and technology and / or other evidence according law have blood relations, including civil relations with his father's family. "4

\footnotetext{
${ }^{1}$ Student of Master of Law, Universitas Islam Sultan Agung Semarang and Islamic Court Deputy Registrar lawsuit of Blora, email: rofiatun.sh@gmail.com

${ }^{2}$ Lecturer of Master of Law, Sultan Agung Islamic University (UNISSULA), Semarang

${ }^{3}$ Lecturer of Master of Law, Sultan Agung Islamic University (UNISSULA), Semarang

${ }^{4}$ Constitutional Court Decision number 46 / PUU-VIII / 2010, p.230
} 
Legal norms the results of the design thought of Judges of the Constitutional Court according to Article 47 of Act No. 24 of 2003 as amended by Act No. 8 of 2011 on the Constitutional Court in effect since completed pronounced judges of the Constitutional Court are final and binding, ${ }^{5}$ among others, the goal is in order to provide legal certainty intended, so that with the ruling by the judges of the Constitutional Court on the 13th of February 2012 automatically or by itself acting as legal norms for the Indonesian nation, so that for the Judges in both the environment agency of the Islamic Courts and in general the environment Courts often examine and adjudicate civil judge actions relating to the rights of women and children must be making it as a guide in deciding the case related lawsuit civil rights of children, including civil rights of children outside of marriage.

In the context of the decision on case number 99 / Pdt.G / 2018 / PA.Rbg who researched the author in this thesis is concerned with civil rights to marry and women beyond child-related custody and inheritance rights of children outside marriage as a victim of a result Sirri polygamous marriages (because both parents have done a polygamous marriage without the permission of the court and not in the poligamy marriage please register to guidelines hear the case of women who are dealing with the legal environment of the Islamic Courts can be applied when judges examine and hear the case Isbat Nikah (marriage legalization) including polygamous marriage lawsuit Isbat as found in decision 99 / Pdt.G / 2018 / PA.Rbg, in this context, women and children are often the victims of man as biological parents.

Act No. 23 of 2002 on the protection of children, confirmed that the definition of a child is a person under 18 (eighteen) years, including the unborn child, while the child protection are all activities to ensure and protect the rights of children and rights in order to live, grow, develop, and participate optimally in accordance with human dignity, and protection from violence and discrimination, while those referred children's rights are part of human rights which must be guaranteed, protected and fulfilled by parents, families, communities, governments, and the state. ${ }^{6}$ Referring to these provisions, it is appropriate if the judge as part of law enforcement officers when checking out and hear the case Isbat Nikah including confirmation of marriage polygamy reality prevalent in today's society, as well as cases origin of the child and / or case of recognition of children treated specifically that the future status of children became apparent, obtain legal protection and access to justice and receive the rights of the biological father accordance proper according to the law he can receive, because the rules of Islamic law is no rule that states: A law was dominant that covers all parts well there provisions and no provisions

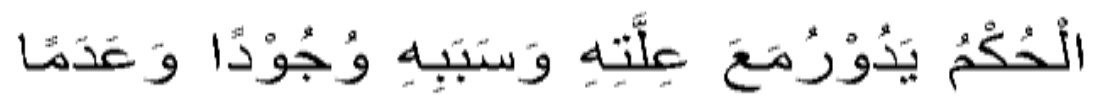

There is and whether the law depends on the cause ('illat) it ${ }^{7}$

Another issue is Isbat polygamous marriage legalization cummulation with children in the decision number 99 / Pdt.G / 2018 / PA.Rbg the law in theory can be categorized as

\footnotetext{
${ }^{5}$ Act No. 24 of 2003 on the Constitutional Court, p.10.

${ }^{6}$ National Law Firm, Act No. 23 of 2002 on Child Protection;

${ }^{7}$ Asymuni A.Rahman, Qoidah - Qoidah Fiqh, Jakarta, Bulan bintang, Ed.1, 1976,p.5
} 
smuggling law, because the Indonesian positive law does not regulate Isbat polygamous marriage while the rules of Islamic law states:

$$
\text { حكم الحا كم فى مسا ئل الاختلا ف رفع الخلا ف }
$$

Which means: "The verdict obviate confusion and legal uncertainty"

Based on the above description, it can be proposed formulation of the problem as follows: Is the civil rights of children outside of polygamous marriage due to confirmation by the Islamic Court of Rembang decision number 99 / Pdt.G / 2018 / PA.Rbg. against men as the biological father together with the civil rights of children born out of and / or due to legal marriage; What legal considerations Islamic Court of Rembang Judge in deciding the case Isbat polygamous marriage with ratification cummulation children outside marriage in decision: 99 / Pdt.G / 2018 / PA.Rbg; and What ljtihad method and how to use law judge code in deciding the case number: 99 / Pdt.G / 2018 / PA.Rbg.

\section{Research Methods}

The approach will be used in this research is a normative juridical approach. Normative legal research, also known as legal research using secondary data sources. ${ }^{9}$

The source of the data obtained in this thesis include secondary data is data obtained indirectly by researchers in the form of legal materials documents or library materials which include materials Legal Primer in the form of legislation and jurisprudence, and material Law secondary form of opinions legal / doctrine / theories derived from the legal literature, research, scientific articles and websites related to the research, legal materials that explain the primary legal materials such as the results of the study, the opinion of legal experts in the form of an interview with Judge as speakers are used as a support to clarify the primary legal materials. ${ }^{10}$ and tertiary legal materials, including materials that provide guidance and explanation of the primary legal materials and secondary legal materials, tertiary legal materials obtained from the legal dictionary, a dictionary Indonesian, English dictionaries, encyclopedias and the like. ${ }^{11}$

Data collection methods used is literature study. The data were analyzed descriptively qualitative.

\section{Results And Discussion}

\section{From The Aspect Of Islamic Legal Theory}

Islamic Court of Rembang Decision that the number 99 / Pdt.G / 2018 / PA. Rbg. The essence is an answer to the request / confirmation lawsuit polygamous marriage. Polygamous marriage confirmation before the publication of the Indonesian Supreme Court Regulation No. 3 of 2018 on the application of the formulation of the results of the meeting room of the Supreme Court Religion. In terms of impact / legal

\footnotetext{
${ }^{8}$ Ibid, p.4

${ }^{9}$ Amirudin, and Zaenal Asikin, Pengantar Metode Penelitian Hukum, Raja Grafindo persada, Jakarta, 2010

${ }^{10}$ Peter Mahmud Marzuki, Metode Penelitian Hukum, Gramedia, Jakarta, 2006, p. 141

${ }^{11}$ Ibid, p. 119
} 
consequences caused by their polygamous Sirri Marriage Isbat actually very positive, among others:

- Marriage is concerned is final and binding, for the post declared the marriage valid, the applicant confirmation report to the Employee Registrar stipulation to be recorded and issued marriage certificate quotation illegitimate;

- Children born out of marriage or polygamous Sirri Marriage/ under hand / undocumented / illegal should be set up as a child of the marriage of his parents who had been declared invalid by the Court of Religion;

- Highly functioning to the benefit of data administration for children's educational interests of children, birth certificates, and marriage.

- Useful for handling cases of inheritance disputes in the Islamic Court.

- Very useful for the basic process of transferring the ownership of property in the form of the name on the ground in his life at the notary and / or Officer of the Land Deed maker based joint property in question. ${ }^{12}$

Opinion or the results of ljtihad judge who helped investigate and adjudicate on case number 99 / Pdt.G / 2018 / PA.Rbg. that, according to the author in line with the rules of Ushul Figh which states: (Adzororu Yuzalu) which means all the things in it (it is believed) contains madzorot (lack of feeling better / not profitable even emergency) if not taken any legal action must be removed. The positive impact (justice based on the benefit of) the other when talking about the civil rights of children outside wedding later declared invalid by the Islamic Court of Rembang decision number 99 / Pdt.G / 2018 / PA.Rbg. The opinion of the author is from the custody of the child if the child's marriage were born female, as in the decision.

Whereas based on data from Islamic Court of Rembang case for 2019 after the publication of the circular letter no matter the request / confirmation lawsuit filed polygamous marriage. ${ }^{13}$ Thus, according to the author, and publication of the Supreme Court Circular letter No. 3 in 2018 on the application of the formulation of the results of the meeting rooms Religion substantive legal field that prohibits the receipt of the lawsuit or petition Isbat polygamous marriage has a negative impact (Madzorot) include:

- Polygamous Sirri Marriage concerned is not legally binding;

- Could not book excerpt published illegitimate deed;

- Children born of polygamous Sirri Marriage as it remains connected to her mother and her mother's family;

- Can not inherit each other over the treasures left behind;

- Could not do joint ownership of property acquired during the marriage bond Sirri polygamy; $^{14}$

\footnotetext{
${ }^{12}$, Results interview with a member of the Assembly of Islamic Court Judge of Rembang (Dr.Drs.Sutiyo, MH.) Which is applied as a judge and adjudicates case number 99 / Pdt.G / 2018 / PA.Rbg.

${ }^{13}$ Results of interviews with Munawir, SH. Deputy Registrar Law on Islamic Court of Rembang on Friday, January 10, 2020.

${ }^{14}$ The results interview with a member of the Assembly of Islamic Court Judge of Rembang (Dr.Drs.Sutiyo, MH.) Which is applied as a judge and adjudicates case number 99 / Pdt.G / 2018 / PA.Rbg.
} 


\section{Review Of The Theory Of Legal Protection Aspects}

That if the ruling Islamic Court of Rembang number 99 / Pdt.G / 2018 / PA. Rbg. viewed from the aspect of legal protection, then surely one of the statutory functions of providing a guarantee of order, regularity, security, justice, peace, certainty and expediency has clearly been achieved, but after post publication of the Circular Letter of the Supreme Court No. 3 of 2018 on the application of the formula results of the meeting rooms religion substantive legal field that no longer allow Islamic Court received a petition Isbat polygamous Sirri Marriage / under hand / undocumented / illegal.

Satjipto Raharjo found that the legal protection essentially provides shelter for human rights are harmed others and the protection given to the public so that they can enjoy all the rights conferred by law. ${ }^{15}$

\section{In Terms of Maqdsid Al Sharia theory}

Viewed from the side of Maqashid Al-Sharia theory what has been decided in court judges in the Islamic Court of Rembang case number (99 / Pdt.G / 2018 / PA.Rbg.) $\mathrm{IMHO}$ very much in line with the Sharia Al- Maqhashid theory because the verdict Islamic Court of Rembang in the suit has a goal of achieving maslahatan dhoruriah (goodness most basic / fundamental) covering five topics, the maintenance of religion or Addin, maintaining soul (nafs), maintenance of reason (aqlu), maintenance of offspring (nashl) and maintenance of the property (mall). ${ }^{16}$ Furthermore, if the terms of the breeding (Hifdu An-Nasl) ruling Islamic Court of Rembang can fulfill the civil rights rights of the child because of the dhoruriyah (principal) civil rights of the child to be fulfilled because after all also children born of polygamous Sirri Marriage it if has arrived time is able to mate normally and avoid adultery. Then in terms of the breeding of hajiyah side or the needs of the children at the time of carrying out the ceremony did not experience any barriers including the right to inheritance from her biological father. ${ }^{17}$

\section{In view of the Theory of Justice.}

That one purpose of the law is to bring about justice for the people, for the law to be sensitive to the values of truth and values of justice and humanity. ${ }^{18}$

Islamic Court of Rembang Decision number 99 / Pdt.G / 2018 / PA.Rbg, validating polygamous Sirri Marriage can be viewed as an answer to the needs of scientific justice for Surohmiyati Petitioner and her children were the result or the legal basis can be felt by a large family of Applicant Surohmiyati Suraji daughter and her children,

\footnotetext{
${ }^{15}$ Satjipto Raharjo, Sosiologi Hukum, Perkembangan Metode Dan Pilihan Masalah, Gentha blissing, Semarang, Ed. II, 2010, p.24.

${ }^{16}$ Ash-Syatibi, op.cit, p.35.

${ }^{17}$ Abdul wahabqolaf, Ibid, p.102

${ }^{18}$ Prof. Sajtipto Rahardjo, Progressive Law as the basis for the development of the Indonesian Legal science paper at a national seminar IAIN Walisongo cooperation and Doctoral Program Diponegoro in Semarang, December 8th, 2004, p. 4
} 
because what does not, by declaring valid polygamous Sirri Marriage who lived since the age of 14 years (age of children) with a man who has been married and childless 9 by judges then justice has been acquired.

\section{Judging from the aspect of legal certainty theory.}

That one of the basic character or tabi'at of destination by Gustav Rrasbruce law is legal certainty with one meaning that in essence legal certainty has been conceived in it justice and legal expediency. ${ }^{19}$

Islamic Court of Rembang Decision number 99 / Pdt.G / 2018 / PA.Rbg. which establishes a valid polygamous Sirri Marriage applicant with her late husband Mansyur Khafid have impoverish law phobia since the age of 14 years to haunt the Petitioner and the children offspring, how not when offspring are the number 1 (one) marrying the polemics on the determination of who man entitled to be guardian of marriage on children outside of marriage.

\section{In the review of the legal aspects of the theory of usefulness.}

Religion Court judgment is in favor / Petition in decision 99 / Pdt.G / 2018 / PA. Rbg. that the verdict declared valid polygamous Sirri Marriage applicant with Mansyur Khafid them is generating pleasure, good or happiness and prevent damage, suffering or evil and unhappiness on the Applicant and its offspring.

According to Jeremy Betham has placed mankind under the arrangement of two sovereign authority (Two Saverengin Masters) are suffering (pain) and joy (pleasure) have both shown what to do by law and determine what will be done by law, the State and the law solely there only for the true benefit of the majority which is happiness in the form of social justice. ${ }^{20}$

\section{Civil Rights Of Children Outside Polygamous Marriage Due Isbat in Islamic Court Of Rembang Decision No. 99 / Pdt.G / 2018 / PA.Rbg.}

From what has been described above can be a common thread related to civil rights to marry as a result of confirmation of children outside Sirri Marriage polygamy / polygyny is not recorded / polygamy under the hand / polygamy is illegal in decision 99 / Pdt.G / 2018 / PA.Rbg. particularly related to child custody when the child is married and heritage rights. Because among the Muslim jurists still debatebel, but according to the author, it is sufficient based on the results of consultation Ulama in Lombok West Nusa Tenggara Indonesia in 2017 that in ljtihad has been agreed:

First, if a woman named Surohmiyati binti Suraji pregnancy after legally marrying Islam (Syar'i) by Mansyur Khafid where marriage performed in accordance with the terms and harmonious marriage in Islam as applicant marriage with the deceased Suraji Surohmiyati bint Mansyur Khafid in decision 99 / Pdt.G / 2018 / PA.Rbg, then apply Nasab legal guardian and the laws of inheritance to him.

\footnotetext{
${ }^{19}$ Teguh Prasetyo, Keadilan Bermartabat Perspektif Teori Hukum, Nusa Media, Bandung 2015, p.113.

20 Amran Su'adi, Sosiologi Hukum,Penegakan, Realitas Dan Nilai Moralitas Hukum, Prenada Media Group, First Edition, Jakarata, 2018, p.65.
} 
second: If it turns out she (Surohmiyati binti Suraji) for example are not married in Islamic law (Syar'i) for example, there are two opinions:

- If a child is born the mother is not married to anyone, then Nasab of child to his mother, so that the civil rights only to her mother and her mother's family just as well as beyond.

- If the child was born after his mother married either by the biological father or others). So If the fetus is born more than six (6) months (of the ceremony), then Nasab it falls to the mother's husband, in this case the late Mansyur Khafid and boys sibling and if there are no sons had the same father offspring Mansyur Khafid. But (b). If the child is born Applicant Surohmiyati-Mansyur Khafid turns born less than six (6) months of the marriage ceremony performed, then the child did not have a good civil rights Nasab, custody, and inheritance rights to her husband.

\section{Closing}

\subsection{Conclusion}

From the description above, in the end it can be concluded as follows:

- That the civil rights of the three children outside marriage Applicant Surohmiyati binti Suraji in Islamic Court of Rembang decision number 99 / Pdt.G / 2018 / PA.Rbg. particularly on Rights and Nasab guardianship and inheritance rights to men as equal to the rights of the biological father biological children Mansyur Khafid descent from the first marriage.

- That the legal reasoning Islamic Court of Rembang Judge who has to decide on case number 99 / Pdt.G / 2018 / PA.Rbg. has been in line with the objective law of the realization of justice, certainty and benefit of the law for the Petitioner Surohmiyati binti Suraji and three children under it and the decision taken by basing the rules of Islamic law that states "Adh-Dzororu Yuzalu" / that danger (that injustice, uncertainty and lack of legal Utilization) must be neutralized or eliminated, thus viewed from the aspect Al-Maqoshid Sharia theory of (Islamic law destination) is aligned, for the birth of a decision on the case is in order to maintain descent (Hifzdun Nasab / nacelle).

- Islamic Court of Rembang Decision that the number 99 / Pdt.G / 2018 / PA.Rbg. is the result of ljtihad judges who are Tathbiqi on legal matters that are not included in the law Materiil Islamic Courts for article 7 paragraph 3 (c) Compilation of Islamic Law in Indonesia allows confirmation of Sirri Marriage polygamy into the Islamic Courts, while the advent of prohibition Isbat marriage polygamy to be submitted request and / or claim Isbat marriage polygamy as in the Circular of the Supreme Court No. 3 of 2018 on the implementation of the results of the meeting rooms Religion field of material law is contrary to the principles and spirit of legal protection, therefore circulars of the Supreme Court deserves to be revisited,

\subsection{Suggestion}

The advice the author of this thesis as follows: 
- It needs a more intensive socialization to the judges of Courts of religion and society and the law enforcement agencies other civil rights of children outside of marriage (as a result of polygamous Sirri Marriage) for mail Circular of the Supreme Court No. 3 of 2018 be revised so that it aligns with the principles and the spirit of legal protection.

- There needs to be a deeper Ijtihad for Islamic Court Judge in realizing the goal of the law of any decision taken.

- Socialization needs in an integrated manner so that people understand correctly that Sirri Marriage and / or Sirri polygamy not in line with the legislation, because of the impact of such marriages more madhorot than good in the realm of law

\section{References}

\section{Books:}

[1] Abdul wahab qholaf, I/mu Ushul fiqih, diterjemahkan oleh Moh Zuhri dan Ahmad Qorib Dinautama semarang 2014.

[2] Amirudin, and Zaenal Asikin, Pengantar Metode Penelitian Hukum, Raja Grafindo persada, Jakarta, 2010

[3] Amran Su'adi, Sosiologi Hukum, Penegakan, Realitas Dan Nilai Moralitas Hukum, Prenada Media Group, First Edition, Jakarata, 2018.

[4] Asymuni A.Rahman, Qoidah - Qoidah Figh, Jakarta, Bulan bintang, Ed.1, 1976.

[5] Bakri As Safri Jaya, Konsep Maqashid Syariahus syariah menurut Asf-Syatibi, Raja Grafindo persada, Jakarta 1996.

[6] Bambang Sunggono, Metode Penelitian Hukum (Suatu Pengantar), Jakarta Raja Grafindo Persada, 1997.

[7] Habiburrahman, Anak Luar Kawin Dalam Putusan Mahkamah Konstitusi, Varia Peradilan tahun XXVII, nomor 317, Jakarta, 2012.

[8] J.Satrio, SH, Hukum keluarga tentang kedudukan anak dalam Undang-undang, edisi revisi, Citra Aditya Bakti, Badung, 2005.

[9] Katib Rasyid, Anak lahir diluar perkawinan (secara hokum) berbeda dengan anak Zina, Materi disampaikan pada seminar Nasional Program Pasca Sarjana, Fakultas Hukum UNISSULA Semarang, 2012.

[10] Peter Mahmud Marzuki, Metode penelitian hukum, Gramedia, Jakarta, 2006.

[11] Subekti, R. Tjitro Sudibyo, KUH. Perdata, Pradya paramita,Jakarta, 1992,

[12] Satjipto Raharjo, Sosiologi Hukum, Perkembangan metode dan pilihan masalah, Gentha blissing, Semarang, Ed. II, 2010.

[13] R.Subekti \& R. Tjitro Sudibyo, Kitab Undang-undang Hukum Perdata, Pradya Paramitha, Jakarta, 1992.

[14] Teguh Prasetyo, Keadilan Bermartabat Perspektif Teori Hukum, Nusa Media, Bandung 2015.

\section{Internet:}

[1] http://islam.nu.or.id/post/read/86884/status -nasab dan hak waris anak luar kawin Ibnu Taimiyah, Al-Muhalla, Beirut libanon, 1994.

[2] www. Badilag. Net. 